\title{
Heavy Metal Concentration and Health Risk Assessment of Selected Fruits Sold in Jos Metropolis
}

David Bayo ${ }^{1}$, Olufunso Adeniyi ${ }^{1 *}$, Adebayo Adeniyi ${ }^{2}$, Oluwole Ariwoola ${ }^{3}$

1. Montane Forest Research Station, Forestry Research Institute of Nigeria, Jos, Plateau State, Nigeria; E-Mails: estyb2009@yahoo.com; adeniyiolufunso@gmail.com; adeniyi.oo@frin.gov.ng

2. Department of Animal Production, Faculty of Agriculture, University of Jos, Plateau State, Nigeria; E-Mail: akunle97@gmail.com

3. Federal College of Forestry Ibadan, Forestry Research Institute of Nigeria, Ibadan, Oyo State, Nigeria; E-Mail: woleariwoola@yahoo.com

* Correspondence: Olufunso Adeniyi; E-Mail: adeniyi.oo@frin.gov.ng

Academic Editor: Zhe-Sheng Chen

Advances in Chemical Research

2021, volume 3 , issue 2

doi:10.21926/acr.2102013
Received:February 27, 2021

Accepted:April 27, 2021

Published: May 12, 2021

\begin{abstract}
The present study investigated the level of heavy metals in selected fruits sold commonly in Jos, Nigeria. The fresh fruits (Avocado pear, Black currant, Egg Plant, Golden melon, and Soursop) were purchased from five major markets (Terminus, Farin Gada, Building materials, Bukuru, and Fobur) in Jos. Each fruit sample was collected in triplicate and analyzed using standard procedures. The concentration of heavy metals ( $\mathrm{Fe}, \mathrm{Cu}, \mathrm{As}, \mathrm{Cd}, \mathrm{Zn}, \mathrm{Pb}, \mathrm{Mn}$, and $\mathrm{Cr}$ ) was determined using Graphite Furnace Atomic Absorption Spectrophotometer. The data obtained were subjected to descriptive statistics and then compared with the WHO/FAO acceptable limits. The results revealed low concentrations of Fe $(0.125-0.241 \mathrm{mg} / \mathrm{kg}), \mathrm{Cu}$ (0.015-0.020 mg/kg), Zn (0.925-1.135 mg/kg), Mn (0.025-0.045 mg/kg), Cr (0.018-0.029 $\mathrm{mg} / \mathrm{kg})$, and $\mathrm{Pb}(0.031-0.055 \mathrm{mg} / \mathrm{kg})$ in all five fruits studied. Only cadmium exceeded the acceptable limit of $0.020 \mathrm{mg} / \mathrm{kg}$ stipulated by WHO/FAO, with the highest cadmium concentration of $0.085 \mathrm{mg} / \mathrm{kg}$ detected in Soursop. Accumulation of cadmium in the kidneys leads to kidney damage and osteoporosis. The Estimated Daily Intake (EDI) values of all
\end{abstract}

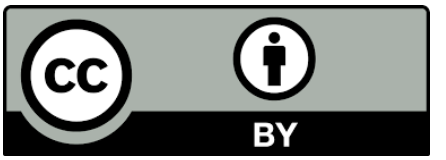

(C)2021 by the author. This is an open access article distributed under the conditions of the Creative Commons by Attribution License, which permits unrestricted use, distribution, and reproduction in any mediumor format, provided the original work is correctly cited. 
metals were lower than the recommended tolerable daily intake values, except for arsenic, for which the hazard quotient greater than 1 was also detected in all the fruits studied. This could be as a result of pollution in the environment of the regions where the fruits were cultivated. Long-term exposure to inorganic arsenic causes cancer. Environmental pollution raises health challenges to the consumers and therefore, drastic measures should be implemented to control it.

\section{Keywords}

Fruits; heavy metals; health risk; Jos metropolis; pollution

\section{Introduction}

Environmental pollution refers to the release of substances that are harmful to humans and other living organism in the environment [1]. These harmful substances could be released into any of the environmental compartments, including soil, water, air, and their interfaces [2], either naturally or through anthropogenic activities. Environmental pollution is a consequence of exponentially increasing population, industrialization, and urbanization [3], which occur in most developing as well as developed nations across the world.

Heavy metals are metals or metalloids with a relatively high density; their atomic density is usually higher than $4 \mathrm{~g} / \mathrm{cm}^{3}$ or five times the density of water [4]. Heavy metals are hazardous even at low concentrations as they are not biodegradable and have long biological half-lives [5-7]. Heavy metals occur naturally in the earth crust, and contaminate the environment through natural mineral rock weathering and various anthropogenic activities [8], such as sludge dumping, municipal wastes, electroplating, fertilizer and pesticide application, mining and smelting of metalliferous ores and metal scraps, etc. $[9,10]$. Examples of heavy metals include chromium (Cr), mercury $(\mathrm{Hg})$, silver $(\mathrm{Ag})$, platinum $(\mathrm{Pt})$, iron $(\mathrm{Fe})$, copper $(\mathrm{Cu})$, arsenic $(\mathrm{As})$, cadmium $(\mathrm{Cd})$, zinc $(\mathrm{Zn})$ [4], magnesium (Mg), and manganese ( $\mathrm{Mn}$ ) [11], among others. Plants uptake heavy metals either through absorption from deposits on the plant parts exposed to polluted environmental media or through irrigation with contaminated water [7]. Heavy metal uptake and bioaccumulation along the food chain raises a great threat and health challenges to humans as well as animals [4]. Heavy metals may also be referred to as trace elements as they are present in minute amounts in different environmental matrices [10, 12]. Certain heavy metals, such as chromium, copper, iron, manganese, magnesium, and zinc, are among the essential nutrients required by the human body for biochemical and physiological processes; and their inadequate supply may lead to deficiency diseases or syndromes. The heavy metals that have no biological significance, such as beryllium, arsenic, aluminium, gallium, gold, mercury, and silver, are considered non-essential. Even though a few of the heavy metals are beneficial or essential, their excessive presence may cause cellular and tissue damage resulting in adverse effects and diseased conditions [10].

Soil pollution has increased dramatically at a high rate over the past few years due to the use of agrochemicals (such as chemical manures, fertilizers, sewage sludge, and pesticides) to increase agricultural productivity $[5,12]$. Although these agrochemicals have been effective in solving the problem of global food insecurity, they have also contributed further to environmental issues [1]. 
These agrochemicals contain heavy metals, and their repeated use leads to a high accumulation of these heavy metals in the soil, thereby polluting the agricultural soils [13]. Plants absorb heavy metals from the contaminated soil, store them within their tissues, and then transfer them to humans via the food chain [14-16]. The use of polluted water for irrigation is another source of heavy metal contamination. Owing to a lack of regulated waste disposal systems, most of the industrial, municipal, and domestic effluents are usually dumped into streams and other water bodies. Farmers use these streams and abandoned contaminated mining ponds to collect water for irrigating their agricultural lands $[8,17]$. Therefore, pollutants from all these sources enter the food chain and eventually bioaccumulate in organisms, thereby causing health hazards.

Fruits are a part of the daily diet of humans and are used widely along with other foods for culinary purposes [4]. Lately, in Nigeria, the awareness regarding the health benefits of fruit consumption due to their high nutrient composition, which assists in maintaining good health and vitality, has increased [18]. Fruit composition is also being used as a preventive and curative measure against various diseases $[19,20]$. Jos, the capital city of Plateau State, Nigeria, is known for the cultivation of a wide range of fruits and vegetables, facilitated by its cool weather and other favorable climatic conditions; the city is therefore referred to as the "fruit and vegetable basket" of the nation [21].

Several cases of food poisoning linked to heavy metal exposure have been reported in Nigeria. Recent example is the case of food poisoning due to acute lead exposure from artisanal mining and processing of gold. This occurred in Zamfara State in March 2010 and killed over 500 children within seven (7) months [22-24]. The University of Port Harcourt Teaching Hospital (UPTH) Cancer registry (2009-2013) reported the prevalence of cancer among the Nigerian people, which has also been linked to heavy metals exposure [25]. The improper use of agrochemicals on agricultural products is reported to be responsible for most of these cases.

The recent increase in awareness regarding the health benefits of fruit consumption in Nigeria [18] has raised a necessity to analyze the heavy metal composition of the fruits that are commonly grown and sold in Jos metropolis. The present research was, therefore, aimed to, determine the levels of heavy metals in the fruits commonly purchased in the region and the health risks associated with the daily intake of these fruits in terms of their potential toxicities. Foreign fruits are expensive and, therefore, accessible to only a small section of the population. Therefore, in the present study, only the locally available fruit varieties were sampled, and their levels of heavy metals were compared to the WHO/FAO recommended limits, to generate necessary information on the risks raised to human health.

\section{Materials and Methods}

\subsection{Description of the Study Area}

Jos is the largest city of Plateau State. It is located within $9^{\circ} 56^{1} \mathrm{~N}$ and $8^{\circ} 53^{1} \mathrm{E}$ and is

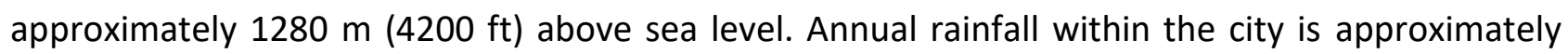
$1400 \mathrm{~mm}$, and the average monthly temperature ranges between $21-25{ }^{\circ} \mathrm{C}[17,26]$. The city is majorly known for the cultivation of fruits and vegetables, although it also has numerous abandoned mines and ponds from the mining activities that began in the $20^{\text {th }}$ century during the colonial period [21]. The contaminated old mines and ponds now serve as sources of water for 
irrigation exposing the farmers to health risks. Farmers that depend on streams for irrigation are also at the risk of contacting contaminated water as wastes are dumped into these streams [8].

\subsection{Sample Collection}

Sample collection was conducted using the methods described in [27, 28]. Fresh samples of five (5) commonly consumed fruits were purchased from five (5) majorly patronized markets located in Jos metropolis, Nigeria. The markets are the Terminus market, Farin Gada market, Building materials (Express) market, Bukuru (Kugia) market, and Fobur market. Each of the fruits was collected randomly in triplicate from different traders in each market, wrapped in polythene bags, labeled appropriately, and carried to the laboratory for analysis. The details regarding the fruits are provided in Table 1.

Table 1 Fruits used in the present study.

\begin{tabular}{lllll}
\hline S/No & Botanical name & Common name & Local/Hausa name & Family \\
\hline 1 & Annona muricata & Soursop & Fasadarur & Annonaceae \\
2 & Perseaamericana & Avocado pear & Avocado & Lauraceae \\
3 & Solanum melongena & Egg plant & Garko & Solanaceae \\
4 & Cucumis melo & Golden or Sweet melon & Zakikankana & Cucurbitaceae \\
5 & Ribes nigrum & Black currant & Baki currant & Grossulariaceae \\
\hline
\end{tabular}

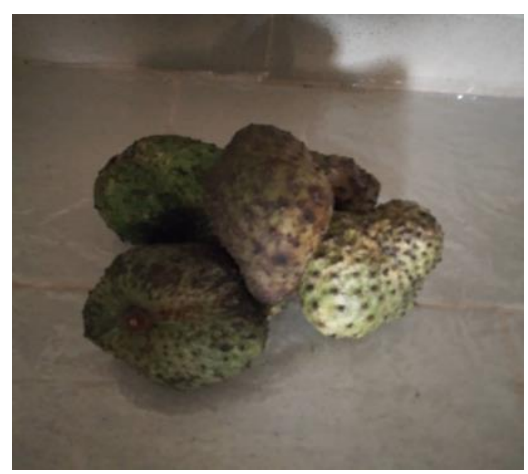

Plate 1: Soursop

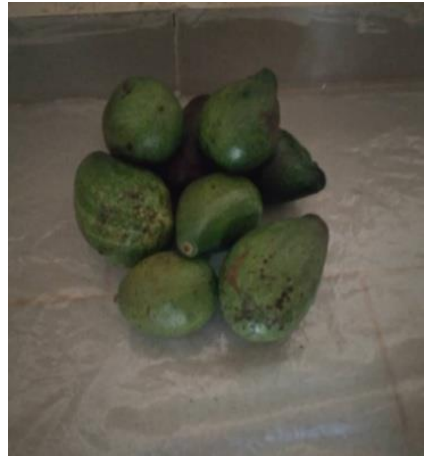

Plate 2: Avocado pear

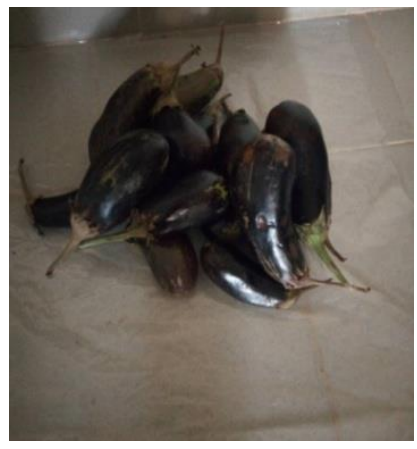

Plate 3: Eggplant
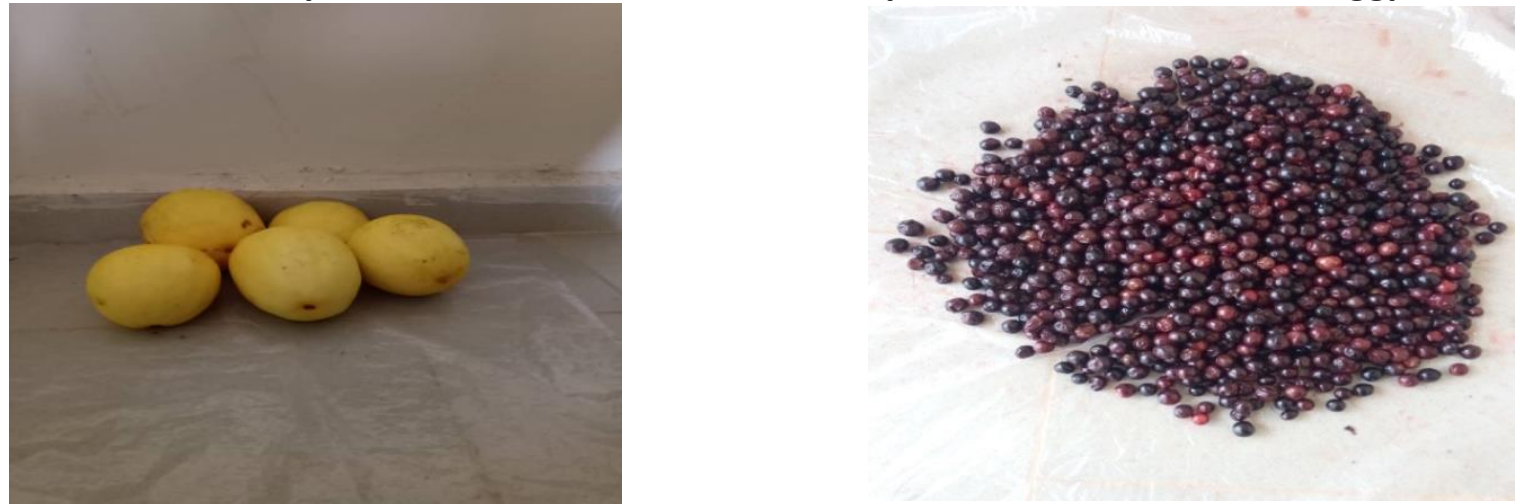

Plate 4: Golden melon or Sweet melon

Plate 5: Blackcurrant 


\subsection{Sample Preparation}

The collected fresh fruit samples were washed thoroughly, first with tap water and then with distilled water, to remove the attached soil particles and other extraneous substances. Each sample was formulated into a composite sample, chopped into smaller pieces using a stainless knife, air-dried for $48 \mathrm{~h}$ and then oven-dried at $70{ }^{\circ} \mathrm{C}$ for approximately $72 \mathrm{~h} \mathrm{[27],} \mathrm{and} \mathrm{finally}$ ground using a porcelain mortar and pestle. The homogenized samples were stored in air-tight bottles and labeled. Representative samples were subsequently digested and analyzed.

\subsection{Heavy Metal Analyses}

The concentrations of different heavy metals in the fruits were determined using the wet acid digestion method. Briefly, $0.2 \mathrm{~g}$ of the homogenized fruit sample was placed in a cleaned and dried Kjeldahl flask, to which, $5 \mathrm{~mL}$ nitric acid and $1 \mathrm{~mL}$ perchloric acid were further added, followed by stirring with glass rods. The flask was then placed on the Kjeldahl heater and heated inside a fume cupboard until its contents became colorless. The digested sample was cooled and filtered into a $100 \mathrm{~mL}$ volumetric flask, and deionized water was added upto the mark on the flask. The solution was then aliquoted into metal-free sample bottles in triplicate and labeled properly for subsequent metal analysis. The concentrations of different heavy metals (iron, copper, arsenic, cadmium, zinc, lead, manganese, and chromium) in the digested solutions of each sample were determined using a graphite furnace atomic absorption spectrophotometer (GFAAS)-PG500, PG Instruments Ltd., Leicestershire, England [29]. The parameters of the GFAAS are presented in Table 2 below.

Table 2 Working Parameters of GFAAS.

\begin{tabular}{lll}
\hline Element & Wavelength $(\mathrm{nm})$ & Flame gases \\
\hline Arsenic & 193.7 & Argon \\
Cadmium & 228.8 & Argon \\
Chromium & 357.9 & Argon \\
Copper & 324.7 & Argon \\
Iron & 248.3 & Argon \\
Lead & 217.0 & Argon \\
Manganese & 279.5 & Argon \\
Zinc & 213.9 & Argon \\
\hline
\end{tabular}

\subsection{Health Risk Assessment Indices}

The health risks raised by the transfer of contaminants from food to humans have been widely studied previously. These risks may be determined using certain indices, such as EDI (Estimated Daily Intake), Hazard Quotient (HQ), Target Hazard Quotient (THQ), Hazard Index (HI), and Daily 
Dietary Intake (DDI), amidst others [30-32]. Two of these indices, EDI and HQ, were considered in the present study.

\subsubsection{Estimated Daily Intake (EDI)}

The daily intake of each of the evaluated heavy metals was determined to estimate the daily concentration of these metals ingested into the human body. EDI was calculated based on the metal concentration in the fruits, the daily consumption amount of the fruits, and the average body weight, using the method described in [30].

$$
E D I=\frac{C_{\text {metal }} x D_{\text {fruit intake }}}{B W_{\text {average }}}
$$

where EDI = estimated daily intake $(\mu \mathrm{g} / \mathrm{kgbw} / \mathrm{day}), \mathrm{C}_{\text {metal }}=$ concentration of the heavy metal in the fruit samples $(\mathrm{mg} / \mathrm{kg}$ ) [30], $\mathrm{D}$ fruit intake = daily intake of the fruit (a minimum of $400 \mathrm{~g}$ of fruits is required per day in less developed countries to reduce micronutrient deficiencies and prevent diseases [33, 34]), BW $\mathrm{BW}_{\text {average }}=$ average body weight of a Nigerian individual $=62 \mathrm{~kg}$ (considering the general population) [31].

\subsubsection{Hazard Quotient}

The risk accompanying the consumption of contaminated food may be evaluated by calculating the hazard quotient $[35,36]$. In the present study, the hazard quotient for adults,associated with the consumption of metals in the selected fruits sold in Jos metropolis, was determined using the following formula:

$$
H Q=\frac{(D) x\left(C_{\text {metal }}\right)}{\left(R_{f} D\right) \times B O}
$$

where $D=$ the daily intake of fruits $(\mathrm{kg} /$ day; a minimum of $400 \mathrm{~g}(0.4 \mathrm{~kg})$ of fruits is required per day in less developed countries $[33,34], C_{\text {metal }}=$ concentration of the heavy metal $(\mathrm{mg} / \mathrm{kg}), \mathrm{Rf}_{\mathrm{f}}=$ reference oral dose of the heavy metal $(\mathrm{mg} / \mathrm{kg}$ of body weight/day), and $\mathrm{BO}=$ body weight $(\mathrm{kg})$, the average body weight of a Nigerian individual was considered to be $62 \mathrm{~kg}$ [31]. The reference oral doses (in $\mathrm{mg} / \mathrm{kg} /$ day) for each of the evaluated heavy metals are as follows: Arsenic-0.0003; Cadmium-0.0010; Chromium-0.0030; Copper-0.0400; Iron-0.7000; Lead- 0.0040; Manganese-0.1400; and Zinc-0.3000 [36-41].

\subsection{Statistical Analysis}

The recorded data were subjected to descriptive statistical analysis to reveal central tendency and dispersion.

\section{Results and Discussion}

The results of the mean concentration of heavy metals in the analyzed fruits are presented in Figure 1. 


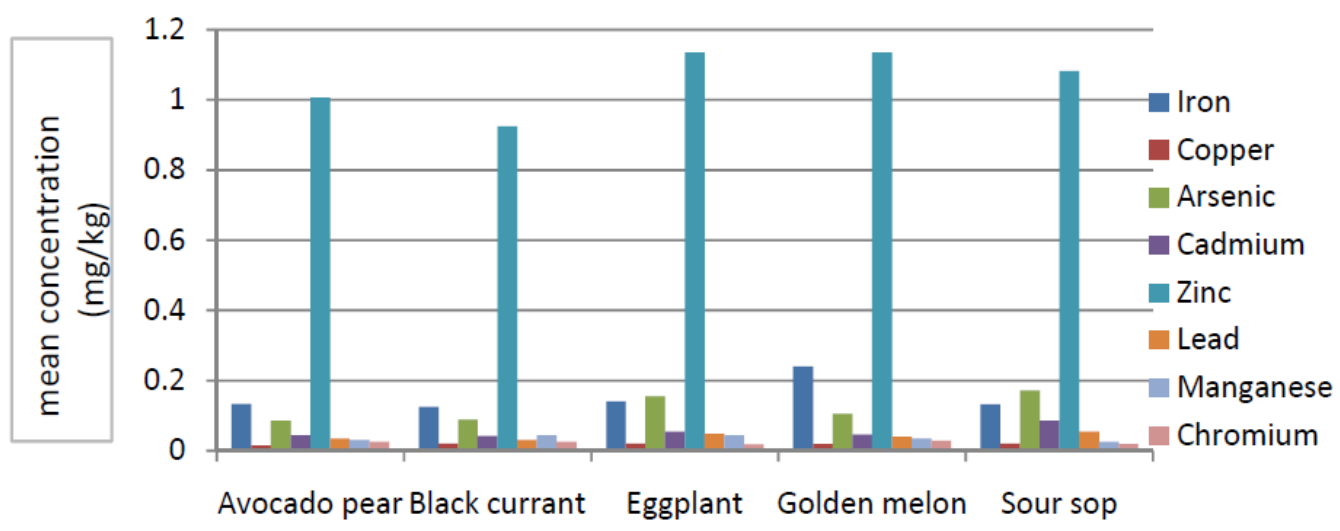

Figure 1 Mean concentrations of heavy metals in the analyzed fruits.

The heavy metal concentrations were then compared to the WHO/FAO acceptable or permissible limits, which are listed in Table 3.

Table 3 WHO/FAO acceptable limits of a few metals.

\begin{tabular}{ll}
\hline Parameters & $\begin{array}{l}\text { WHO/FAO Acceptable Limits } \\
(\mathbf{m g} / \mathbf{k g})\end{array}$ \\
\hline Iron & 1.00 \\
Copper & 2.00 \\
Cadmium & 0.02 \\
Zinc & 1.50 \\
Lead & 0.50 \\
Manganese & 5.00 \\
\hline
\end{tabular}

Source: (Oyareme et al., [42])

The Estimated Daily Intake (EDI) values for each of the evaluated heavy metals are presented in Figure 2.

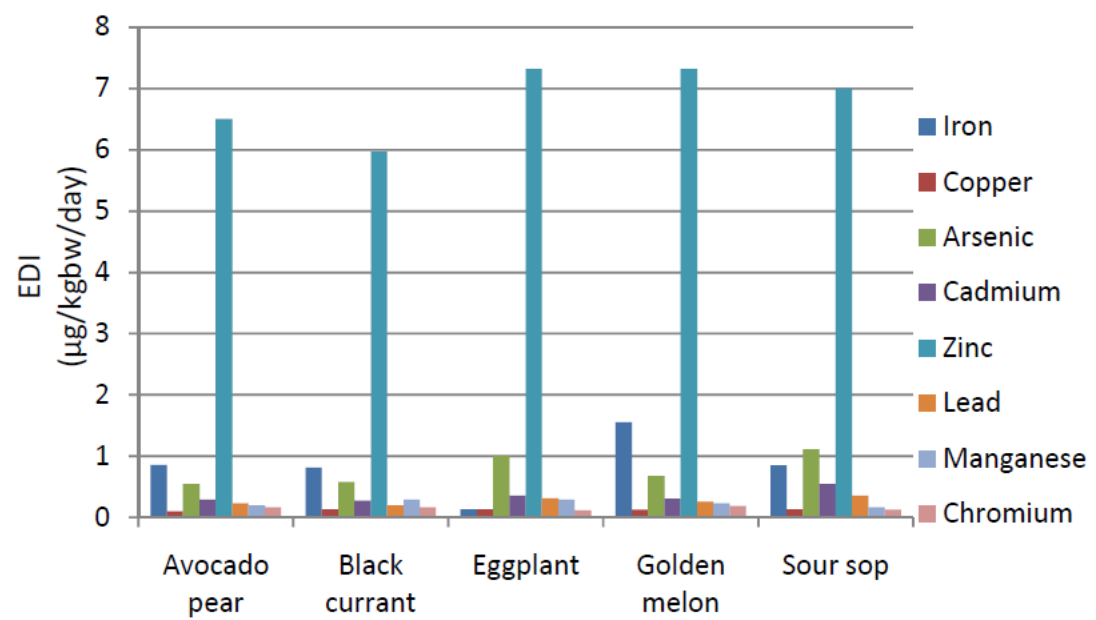

Figure 2 Estimated Daily Intake (EDI) values for metals ( $\mu \mathrm{g} / \mathrm{kgbw} /$ day) based on the consumption of $400 \mathrm{~g}$ of fruits per day in less developed countries. 
The estimated daily intake values and the hazard quotients for the evaluated heavy metals are presented in Figure 2 and Table 4, respectively.

Table 4 Hazard quotients of the evaluated metals in the analyzed fruits.

\begin{tabular}{lllllllll}
\hline Fruits & $\mathrm{Fe}$ & $\mathrm{Cu}$ & $\mathrm{As}$ & $\mathrm{Cd}$ & $\mathrm{Zn}$ & $\mathrm{Pb}$ & $\mathrm{Mn}$ & $\mathrm{Cr}$ \\
\hline $\begin{array}{l}\text { Avocado } \\
\text { pear }\end{array}$ & 0.0012 & 0.0024 & 1.8280 & 0.2903 & 0.0216 & 0.0565 & 0.0014 & 0.0538 \\
$\begin{array}{l}\text { Black } \\
\text { currant }\end{array}$ & 0.0012 & 0.0032 & 1.9140 & 0.2710 & 0.0199 & 0.0500 & 0.0021 & 0.0538 \\
$\begin{array}{l}\text { Eggplant } \\
\text { Golden }\end{array}$ & 0.0013 & 0.0032 & 3.3333 & 0.3548 & 0.0244 & 0.0774 & 0.0021 & 0.0387 \\
$\begin{array}{l}\text { melon } \\
\text { Soursop }\end{array}$ & 0.0022 & 0.0031 & 2.2581 & 0.3032 & 0.0244 & 0.0645 & 0.0016 & 0.0624 \\
\hline
\end{tabular}

Fe-Iron, Cu-Copper, As-Arsenic, Cd-Cadmium, Zn-Zinc, Pb-Lead, Mn-Manganese, Cr-Chromium

Heavy metals interfere with the nutritive value of fruits. The presence of heavy metals in excessive amounts harms human health. Various national and international bodies have established regulations regarding the permissible limits of toxic metals in foods consumed by humans. These limits are expected to be strictly adhered to in order to limit the heavy metal concentration in foods [42] to the recommended daily intake values and thereby reduce the risks to human health. Although a few of the heavy metals evaluated in the present study are essential nutrients and play beneficial roles in the physiological and biochemical processes occurring within the human body when consumed in minute amounts, they might become toxic when consumed at higher concentrations.

Iron serves as a cofactor in different metabolic processes occurring the cellular level, such as lipid metabolism, tricarboxylic acid cycle, respiration, and DNA (deoxyribonucleic acid) synthesis [43]. Iron may form free radicals and become toxic at high concentrations; increased iron absorption causes siderosis (high concentration of iron in tissues) and hemochromatosis, a disorder that leads to diabetes, cirrhosis, liver cancer, and heart disease [43]. The concentration of iron detected in all the analyzed fruits (from Jos metropolis) ranged between 0.125 and 0.241 $\mathrm{mg} / \mathrm{kg}$, which is well within the WHO/FAO acceptable iron limit of $1.00 \mathrm{mg} / \mathrm{kg}$ reported by Oyareme et al., [42]. This suggests that the fruits consumed within Jos metropolis do not contain high levels of iron. Egharevba et al., [19] observed a higher mean concentration of iron ranging between 171.62 and $304.44 \mathrm{mg} / \mathrm{kg}$ in fruits and vegetables sold in Benin City, Nigeria. An iron concentration of $1.24 \mathrm{mg} / 100 \mathrm{~g}$ was reported by Malgorzata and Piotr [44] in black currant fruit from Poland. In the present study, the estimated daily intake of iron, presented in Figure 2, ranged from 0.129 to $1.550 \mu \mathrm{g} / \mathrm{kgbw} /$ day, with eggplant presenting the lowest value while golden melon presented the highest value. These values are lower than the recommended tolerable daily intake value of $12,500 \mu \mathrm{g} /$ day reported in $[30,45]$. A hazard quotient of less than 1 indicates that the level of risk raised by the metal is negligible, while that higher than 1 indicates that the metal may cause serious health risks to the consumer [36]. The hazard quotient for iron in all the fruits 
analyzed in the present study was less than 1 , as presented in Table 4, implying that the consumption of these fruits is not hazardous with respect to iron.

Copper is an essential mineral that serves as a cofactor for various enzymes required for connective tissue synthesis, iron metabolism, and energy production [46]. Prolonged exposure to copper causes diarrhea, vomiting, headache, and dizziness. High uptake of copper may damage the liver and the kidneys, and may even lead to death. WHO/FAO recommends an acceptable limit of $2.00 \mathrm{mg} / \mathrm{kg}$ for copper [42]. The fruits analyzed in the present study had copper in concentrations ranging from 0.015 to $0.02 \mathrm{mg} / \mathrm{kg}$, which does not exceed the acceptable limit. The levels of copper in avocado pear fruit analyzed in the present study were lower than the 3.10 $\mathrm{mg} / \mathrm{kg}$ value reported in [47]. The estimated daily intake of copper, presented in Figure 2, ranged from 0.097 to $0.129 \mu \mathrm{g} / \mathrm{kgbw} / \mathrm{day}$, which is also below the Recommended Daily Intake of $2 \mathrm{mg}$ [48]. The hazard quotient of copper in all the analyzed fruits was less than 1.

Arsenic plays vital roles in growth, survival, fertility, and reproduction in humans and other mammals. Arsenic may ensure optimum mitochondrial membrane function in cardiac muscle cells [49]. Ingestion of inorganic arsenic (trivalent arsenite and pentavalent arsenate) may reduce blood cell production, which could lead to abnormal heart rhythm and fatigue. Long-term oral exposure to inorganic arsenic leads to the appearance of dark patches on the skin and, in certain cases, cancer [50]. Among all the fruits analyzed in the present study, soursop had the highest concentration of arsenic, i.e., $0.172 \mathrm{mg} / \mathrm{kg}$. The Provisional Tolerable Daily Intake (PTDI) for inorganic arsenic was determined to be $0.0002 \mathrm{mg} / \mathrm{kg}$ bodyweight $(0.2 \mu \mathrm{g} / \mathrm{kg}$ body weight) for a 60-kg adult in [51]. The estimated daily intake for arsenic calculated in the present study was in the range of $0.548-1.110 \mu \mathrm{g} / \mathrm{kgbw} / \mathrm{day}$, and its hazard quotient was greater than 1 in all the analyzed fruits, as presented in Figure 2 and Table 4, respectively. The EDI of arsenic was higher than the permissible limit and the same was true for the hazard quotient. Therefore, it is inferred that the analyzed fruits may raise a high health risk to consumers due to the detected levels of arsenic in them.

Cadmium is a highly toxic heavy metal; it is non-degradable, relatively soluble in water, and has a high tendency to bioaccumulate. Cadmium accumulates in the kidneys and leads to kidney damage, kidney stones, hypercalciuria, osteoporosis, and disturbance in the calcium metabolism, among other toxic effects [52]. Ikechukwu et al. [31] detected cadmium at a concentration of $0.036 \mathrm{ppm}(0.036 \mathrm{mg} / \mathrm{kg})$ in soursop fruit purchased from the Ubani market in Umuahia, Abia State, Nigeria. The concentration of cadmium in all the fruits analyzed in the present study was higher than the WHO/FAO acceptable limit of $0.02 \mathrm{mg} / \mathrm{kg}$, with the highest concentration $(0.085$ $\mathrm{mg} / \mathrm{kg}$ ) observed in soursop, a highly beneficial fruit [53]. The highest estimated daily intake value of $0.548 \mu \mathrm{g} / \mathrm{kgbw} /$ day recorded for cadmium was also in soursop. Despite the high concentration of cadmium in all the analyzed fruits, the hazard quotient (health risk) for each fruit was less than 1. A high cadmium concentration was also observed in all the fruits analyzed by lkechukwu et al. [31], who also reported a hazard quotient below 1 for each of the fruits. This indicates that cadmium raises no adverse health threats.

Zinc is a dietary trace element that performs catalytic, structural,as well as regulatory functions. Zinc maintains the structure of enzymes, such as Cu.Zn superoxide dismutase, and also regulates gene expression [54,55]. All the fruits analyzed in the present study had zinc within the acceptable limit of $1.50 \mathrm{mg} / \mathrm{kg}$, with blackcurrant presenting the lowest zinc concentration of $0.925 \mathrm{mg} / \mathrm{kg}$. A zinc concentration of $0.38 \mathrm{mg} / 100 \mathrm{~g}$ was reported in the blackcurrant fruit from 
Poland [44]. The estimated daily intake of zinc calculated in the present study ranged from 5.970 to $7.320 \mu \mathrm{g} / \mathrm{kgbw} /$ day, which is lower than the recommended daily intake of $40,000 \mu \mathrm{g} / \mathrm{day}$ for adults [30]. The hazard quotient for zinc in all the analyzed fruits was less than 1.

The levels of lead detected in the analyzed fruits ranged between $0.031 \mathrm{mg} / \mathrm{kg}$ and 0.055 $\mathrm{mg} / \mathrm{kg}$. None of the fruits had lead concentrations exceeding the acceptable limit of $0.50 \mathrm{mg} / \mathrm{kg}$. Kalagbor and Diri [47] reported a lead concentration of $1.69 \mathrm{mg} / \mathrm{kg}$ in the avocado pear from Rivers State, Nigeria, while a lower concentration of $0.035 \mathrm{mg} / \mathrm{kg}$ was detected in the present study. Lead is toxic even at low concentrations. Lead has no role in cell metabolism [56]. It persists in the environment for longer durations and has become a global environmental hazard [57]. It is also a threat to human health due to its effects on the renal, hepatic, neurological, immunological, and cardiovascular systems in humans [36]. The highest estimated daily intake of lead in the fruits analyzed in the present study was $0.355 \mu \mathrm{g} / \mathrm{kgbw} /$ day, which is below the WHO recommended tolerable daily intake of $240 \mu \mathrm{g} /$ day for adults $[30,58]$. The hazard quotient for lead in all the analyzed fruits was less than 1.

Manganese is crucial for carbohydrate, lipid, protein, and amino acid metabolisms, and is involved in the synthesis and activation of several enzymes, such as manganese superoxide dismutase, glutamine synthetase, transferases, lyases, and isomerases [59,60]. Chronic exposure to manganese causes extrapyramidal syndrome (having similarities with Parkinson's disease), while its acute exposure causes manganism [59]. The concentration of manganese in the fruits analyzed in the present study was below the acceptable or permissible limit of $5.00 \mathrm{mg} / \mathrm{kg}$. A mean concentration of manganese ranging from 0.558 to $0.692 \mathrm{mg} / \mathrm{kg}$ was reported by Egharevba et al. [19] in the fruits and vegetables sold in Benin City. The Estimated daily intake ranging from 0.161 to $0.290 \mu \mathrm{g} / \mathrm{kgbw} /$ day was detected in the present study, which is lower than the 2-11 $\mathrm{mg} /$ day value recommended by the National Research Council of Canada (NRC) as the safe and tolerable daily manganese intake value for adults [30,61]. The hazard quotient for manganese in all the analyzed fruits was less than 1.

Chromium could either be beneficial or hazardous, depending on its oxidation state. Chromium enters the environmental media (soil, water, and air) in the form of chromium (III) and chromium (VI) through various natural processes and anthropogenic activities. Uptake of Chromium (III) by plants is quite common.Chromium (III) is a vital nutrient that occurs naturally in fruits, vegetables, grains, and meat. It plays a major role in lipid, protein, and carbohydrate metabolisms, and may also act as an antioxidant. Consumption of chromium (III) at high concentrations may cause skin rashes. The adequate intake levels of chromium for adult males range between $35 \mu \mathrm{g}$ and $51 \mu \mathrm{g}$, while those for adult females are in the range of 20-24 $\mu \mathrm{g}[62,63]$. Chromium (IV) and (VI) are dangerous to human health [63]. Adverse health effects of chromium (VI) include dermatitis, ulceration and perforation of the nasal septum mucous membrane, and cancer [64]. The concentration of chromium in the fruits analyzed in the present study was between 0.018 and $0.029 \mathrm{mg} / \mathrm{kg}$, with the highest estimated daily intake of $0.187 \mu \mathrm{g} / \mathrm{kgbw} /$ day in golden melon. The Joint FAO/WHO Expert Committee on Food Additives (JECFA) has recommended a daily intake of $200 \mu \mathrm{g} /$ day for chromium [51]. The hazard quotient for chromium in all the analyzed fruits was less than 1.

It is recommended to conduct further studies involving the analysis of soil samples from the sites where these fruits are cultivated to assess the possible transfer of cadmium and arsenic from these soils to the fruits. 


\section{Conclusion}

Among all the heavy metals analyzed in the present study, the concentration of only cadmium $(0.045-0.085 \mathrm{mg} / \mathrm{kg})$, in the analyzed fruits, exceeded the limits recommended by WHO and FAO $(0.02 \mathrm{mg} / \mathrm{kg})$. However, this should not be of major concern as this would not lead to any toxicological risk, considering the fact that the hazard quotient values for all fruits were less than 1. However, the estimated daily intake (EDI) values $(0.548-1.110 \mu \mathrm{g} / \mathrm{kgbw} /$ day) and the hazard quotient (HQ) of 1.8280-3.6989 units detected for arsenic in each of the fruits exceeded the permissible limits. This could be attributed to the pollution in the environments in which these fruits were cultivated. Exposure to the high levels of arsenic in fruits may raise health challenges to consumers. It is further suggested that farmers should be educated regarding the proper use of agrochemicals, and the government should ensure strict regulatory measures and policies to implement acceptable protocols for crop protection and yield improvement. Mandatory monitoring of fruits by food and agricultural agencies, including the Standards Organization of Nigeria (SON), to assess the toxic heavy metals in fruits would ensure the prevention of the bioaccumulation of these metal contaminants along the food chain.

\section{Acknowledgement}

The authors are grateful to the staff of the Biochemistry Division of the National Veterinary Research Institute, Vom, Jos, Nigeria for the assistance rendered in the course of this research.

\section{Author Contributions}

Bayo D. co-designed the study, was responsible for the collection of some of the fruit samples within the study areas and revised the manuscript. Adeniyi O. the corresponding author, designed the study, prepared and wrote the manuscript. Adeniyi A. also collected some of the fruit samples, supervised the experiments and edited the manuscript. Ariwoola O. carried out the data analysis and edited the manuscript.

\section{Competing Interests}

The authors have declared that no competing interests exist.

\section{References}

1. Appannagari RR. Environmental pollution causes and consequences: A study. North Asian Int Res J Soc Sci Humanit. 2017; 3: 151-161.

2. Masindi V, Muedi KL. Environmental contamination by heavy metals. Heavy Met. 2018; 10 : 115-132.

3. Dafaelseed MS, Eltayeb MM, Hassan AB, Babiker EE. Heavy metals and pesticides residue in commercial fresh vegetables in Sudan. In: Science, technology and sustainability in the Middle East and North Africa. Section VI. Geneva: Inderscience Enterprises Limited; 2007. pp.347-354.

4. Onakpa MM, Njan AA, Kalu OC. A review of heavy metal contamination of food crops in Nigeria. Ann Glob Health. 2018; 84: 488-494. 
5. Tasrina RC, Rowshon A, Mustafizur AM, Rafiqul I, Ali MP. Heavy metals contamination in vegetables and its growing soil. J Environ Anal Chem. 2015; 2: 3.

6. Heidarieh M, Maragheh MG, Shamami MA, Behgar M, Ziaei F, Akbari Z. Evaluate of heavy metal concentration in shrimp (penaeussemisulcatus) and crab (portunuspelagicus) with INAA method. SpringerPlus. 2013; 2: 72.

7. Dorcas OJ, Joseph NE, Sunday JS. Determination of the contamination levels of cadmium, lead, arsenic and mercury in the vegetables from old mining site of Jos Plateau, Nigeria. Int J Interdiscip Res Innov. 2016; 4: 40-44.

8. Dingkwoet JD, Solomon MD, Gabriel SM. Comparative study of some heavy and trace metals in selected vegetables from four local government areas of Plateau State, Nigeria.IOSR J Environ Sci Toxicol Food Technol. 2013; 6: 86-93.

9. Ogundiran $\mathrm{MB}$, Osibanjo O. Heavy metal concentrations in soils and accumulation in plants growing in a deserted slag dumpsite in Nigeria. Afr J Biotechnol. 2008; 7: 3053-3060.

10. Tchounwou PB, Yedjou CG, Patlolla AK, Sutton DJ. Heavy metal toxicity and the environment. Mol Clin Environ Toxicol. 2012; 101: 133-164.

11. Haddad NS, Alasadi SZ, Haddad HH. Contamination of heavy metals (lead, zinc, magnesium and manganese) concentrations in human eyes. Am J Anal Chem. 2012; 3: 491-494.

12. Eid EM, El-Bebany AF, Taher MA, Alrumman SA, Galal TM, Shaltout KH, et al. Heavy metal bioaccumulation, growth characteristics, and yield of pisum sativum I. grown in agricultural soil-sewage sludge mixtures. Plants. 2020; 9: 1300.

13. Kayastha SP. Heavy metal pollution of agricultural soils and vegetables of Bhaktapur district, Nepal. Sci World. 2014; 12: 48-55.

14. Maton SM, Dogo JD, Nesla RA, Ali AY. Environmental impact of pesticides usage on farmlands in Nigeria.Int J Innov Res Dev. 2016; 5: 311-317.

15. Emurotu JE, Onianwa PC. Bioaccumulation of heavy metals in soil and selected food crops cultivated in Kogi State, north central Nigeria. Environ Syst Res. 2017; 6: 21.

16. Sandeep G, Vijayalatha KR, Anitha T. Heavy metals and its impact in vegetable crops. Int J Chem Stud. 2019; 7: 1612-1621.

17. Lenka JL, Lepzem NG, Mankilik MM, Dafil RP. Heavy metal contamination in selected cruciferous vegetables grown in Jos Nigeria. Int J Curr Res Chem Pharm Sci. 2018; 5: 26-34.

18. Banwat ME, Lar LA, Daboer J, Audu S, Lassa S. Knowledge and intake of fruit and vegetables consumption among adults in an urban community in North Central Nigeria. Nig Health J. 2012;12: 12-15.

19. Egharevba I, Aluyor E, Ossai J, Oiwoh O. Assessment of heavy metals contamination in vegetables and fruits sold in Benin City, Edo State, Nigeria. Nig Res J Eng Environ Sci. 2017; 2: 161-168.

20. Ogunlaja OO, Moodley R, Baijnath H, Jonnalagadda SB. Nutritional evaluation, bioaccumulation and toxicological assessment of heavy metals in edible fruits of ficussurforssk (Moraceae). J EnvironSci Health B. 2017; 52: 84-91.

21. Wapwera SD, Ayanbimpe GM, Odita CE. Abandoned mine, potential home for the people: A case study of jos plateau tin-mining region. J Civil Eng Archit. 2015; 9: 429-445.

22. Joint UN, Unit OE. Lead pollution and poisoning crisis. Environmental Emergency Response Mission, Zamfara State, Nigeria [Internet]. Switzerland: Joint UNEP/OCHA Environment Unit; 2010.

Available

from: 
https://www.unocha.org/sites/unocha/files/Lead\%20Pollution\%20and\%20Poisoning\%20Crisis \%20Environmental\%20Emergency\%20Response\%20Mission\%20Zamfara\%20State\%20Nigeria \%202010.pdf.

23. Galadima A, Garba ZN. Heavy metals pollution in Nigeria: Causes and consequences. Elixir Pollut. 2012; 45: 7917-7922.

24. Pepple N. Environment and food poisoning: Food safety knowledge and practice among food vendors in Garki, Abuja-Nigeria. J Health Educ Res Dev. 2017; 5: 2.

25. Anyanwu BO, Ezejiofor AN, Igweze ZN, Orisakwe OE. Heavy metal mixture exposure and effects in developing nations: An update. Toxics. 2018; 6: 65.

26. Nigerian Meteorological Agency. Weather of Jos-Plateau [Internet]. Abuja: Nigerian Meteorological Agency; 2017. Available from: https://www.nimet.gov.ng/.

27. Nankishore A. Heavy metal levels in leafy vegetables from selected markets in Guyana. J Agricultura technol. 2014; 10: 651-663.

28. Adedokun AH, Njoku KL, Akinola MO, Adesuyi AA, Jolaoso AO. Potential human health risk assessment of heavy metals intake via consumption of some leafy vegetables obtained from four market in Lagos Metropolis, Nigeria. J Appl Sci Environ Manage. 2016; 20: 530-539.

29. AOAC International. AOAC official method 975.03 metals in plants and pet foods: Atomic spectrophotometric method [Internet]. Rockville, MD: Association of Official Analytical Chemists; $1975 . \quad$ Available from: https://scirp.org/reference/referencespapers.aspx?referenceid=2783175.

30. Arigbede OE, Olutona GO, Dawodujo MO. Dietary intake and risk assessment of heavy metals from selected biscuit brands in Nigeria. J Heavy MetToxic Dis. 2019; 4: 3.

31. Ikechukwu UR, Okpashi VE, Oluomachi UN, Paulinus NC, Obiageli NF, Precious O. Evaluation of heavy metals in selected fruits in Umuahia market, Nigeria: Associating toxicity to effect for improved metal risk assessment. J Appl Biol Biotechnol. 2019; 7: 39-45.

32. Rai PK, Lee SS, Zhang M, Tsang YF, Kim KH. Heavy metals in food crops: Health risks, fate, mechanisms, and management. Environ Int. 2019; 125: 365-385.

33. Agudo A. Measuring intake of fruits and vegetables [Internet]. Genève: World Health Organizational; $2004 . \quad$ Available from: https://apps.who.int/iris/bitstream/handle/10665/43144/9241592826 eng.pdf?sequence=1 \&isAllowed=y.

34. Amao I. Vegetables-importance of quality vegetables to human health. In: Health Benefits of Fruits and Vegetables: Review from Sub-Saharan Africa. London: IntechOpen; 2018. pp.33-53.

35. US Environmental Protection Agency. Risk assessment guidance for superfund: Human health evaluation manual [part A]: Interim final [Internet]. Washington, DC: US Environmental Protection $\quad$ agency; $1989 . \quad$ Available from: https://www.epa.gov/sites/production/files/2015-09/documents/rags a.pdf.

36. Sharma A, Katnoria JK, Nagpal AK. Heavy metals in vegetables: Screening health risks involved in cultivation along wastewater drain and irrigating with wastewater. SpringerPlus. 2016; 5: 488.

37. Regional Screening Level. Summary table [Internet]. Washington, DC: United States Environmental Protection Agency; 2020. Available from: https://semspub.epa.gov/work/HQ/400431.pdf. 
38. US Environmental Protection Agency. Regional screening levels (RSLs)-Generic tables [Internet]. Washington, DC: US Environmental Protection Agency; 2015. Available from: http://www.epa.gov/reg3hwmd/risk/human/rbconcentration table/Generic Tables/index.ht $\underline{\mathrm{m}}$.

39. Wilbur S, Abadin H, Fay M, Dianyi Y, Tencza B, Ingerman L, et al. Toxicological profile for chromium [Internet]. Atlanta, GA: Agency for Toxic Substances and Disease Registry; 2008. Available from: https://www.ncbi.nlm.nih.gov/books/NBK158855/.

40. US Environmental Protection Agency. Exposure factors handbook-general factors [Internet]. Washington, DC: US Environmental Protection Agency; 1997. Available from: http://www.epa.gov/ncea/pdfs/efh/front.pdf.

41. Williams M, Todd GD, Roney N, Crawford J, Coles C, McClure PR. et al. Toxicological profiles [Internet]. Bethesda, MD: National Center for Biotechnology Information (NCBI); 2012. Available

from:

https://www.ncbi.nlm.nih.gov/books/NBK158873/table/T43/?report=objectonly.

42. Oyareme V, Akpogheneta SE, Iloba BN, Ogidiagba F. Occurrence and concentration of heavy metals in garden egg, tomatoes, cucumber and watermelon from two major markets in Edo State, Nigeria. Food Public Health. 2020; 10: 63-67.

43. Cairo G, Bernuzzi F, Recalcati S. A precious metal: Iron, an essential nutrient for all cells. Genes Nutr. 2006; 1: 25-39.

44. Grembecka M, Szefer P. Comparative assessment of essential and heavy metals in fruits from different geographical origins. Environ Monit Assess. 2013; 185: 9139-9160.

45. National Research Council. Recommended dietary allowance. 10th ed. Washington: National Academy Press; 1989.

46. National Institutes of Health. Chromium: Health information [Internet]. Bethesda: National Institutes of Health; 2020. Available from: https://ods.od.nih.gov/factsheets/Chromium-HealthProfessional/.

47. Ihesinachi K, Eresiya D. Evaluation of heavy metals in orange, pineapple, avocado pear and pawpaw from a farm in Kaani, Bori, Rivers State Nigeria. Int Res J Public Environ Health. 2014; 1: 87-94.

48. Lenntech BV. Recommended daily intake of vitamins and minerals [Internet]. South Miami, FL: Lenntech; 2020. Available from: https://www.lenntech.com/recommended-daily-intake.htm.

49. Vibrant Health. Nutritional Value of Arsenic [Internet]. Shelton, CT: New England Greens LLC.; 2018. Available from: https://vibranthealth.com/info-hq/nutritional-value-of-arsenic/.

50. Agency for Toxic Substances and Disease Registry. Toxicological profile for arsenic [Internet]. New York: Agency for Toxic Substances and Disease Registry; 2007. Available from: https://www.atsdr.cdc.gov/ToxProfiles/tp.asp?id=22\&tid=3.

51. Joint FAO/WHO Expert Committee on Food Additives. Summary and conclusion [Internet]. Rome: JECFA/61/SC Sixty-first meeting; 2003. Available from: https://www.wam.go.jp/wamappl/bb11gs20.nsf/0/49256fe9001b533f49256ef4002474e9/\$FI LE/2-1 1.pdf.

52. Nordic Council of Ministers-WHO. Cadmium review [Internet]. Copenhagen: Nordic Council of Ministers-WHO; 2003. Available from: https://pdf4pro.com/amp/view/nordic-council-of-ministers-who-1a7033.html. 
53. Jimoh OA, Ayedun ES, Oyelade WA, Oloruntola OD, Daramola OT, Ayodele SO, et al. Protective effect of soursop (Annona muricatalinn.) juice on oxidative stress in heat stressed rabbits. J Anim Sci Technol. 2018; 60: 28.

54. Bhowmik D, Chiranjib K, Kumar S. A potential medicinal importance of zinc in human health and chronic. Int J Pharm. 2010; 1: 05-11.

55. King JC. Zinc: An essential but elusive nutrient. Am J Clin Nutr. 2011; 94: 679S-684S.

56. Hadi F, Aziz T. A mini review on lead (Pb) toxicity in plants. J Biol Life Sci. 2015; 6: 91-101.

57. Gillis BS, Arbieva Z, Gavin IM. Analysis of lead toxicity in human cells. BMC Genom. 2012; 13: 344.

58. García-Rico L, Leyva-Perez J, Jara-Marini ME. Content and daily intake of copper, zinc, lead, cadmium, and mercury from dietary supplements in Mexico. Food Chem Toxicol. 2007; 45: 1599-1605.

59. Li L, Yang X. The essential element manganese, oxidative stress, and metabolic diseases: Links and interactions. Oxid Med Cell Longev. 2018; 2018: 7580707.

60. Silva CS, Moutinho C, Ferreira da Vinha A, Matos C. Trace minerals in human health: Iron, zinc, copper, manganese and fluorine. Int J Sci Res Methodol. 2019; 13: 57-80.

61. Institute of Medicine. Dietary reference intakes: Applications in dietary planning [Internet]. Washington, DC: The National Academies Press; 2003. Available from: https://pubmed.ncbi.nlm.nih.gov/25057648/.

62. Pechova A, Pavlata L. Chromium as an essential nutrient: A review. Veterinarni Med. 2007; 52: 1-18.

63. Lenntech BV. Health and environmental effects of chromium [Internet]. South Miami, FL: Lenntech B.V.; 2021. Available from: https://www.lenntech.com/periodic/elements/cr.htm.

64. Rambabu K, Bharath G, Banat F, Show PL. Biosorption performance of date palm empty fruit bunch wastes for toxic hexavalent chromium removal. Environ Res. 2020; 187: 109694.

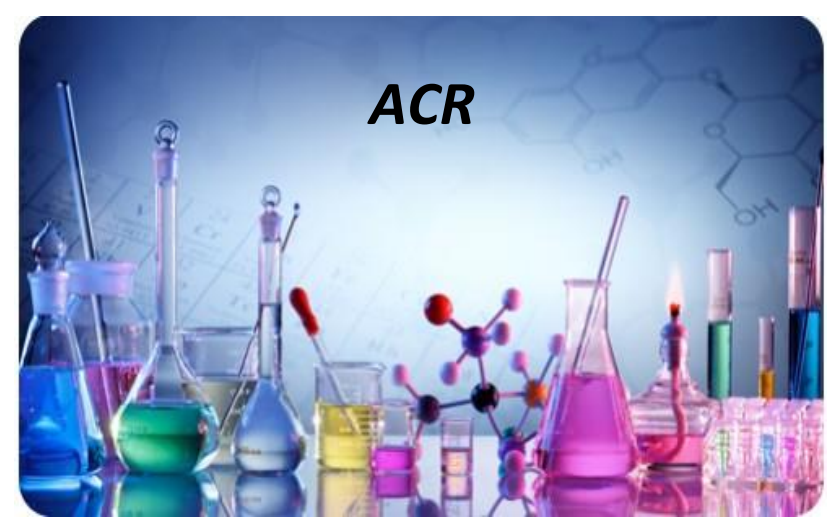

Enjoy ACRby:

1. Submitting a manuscript

2. Joining in volunteer reviewer bank

3. Joining Editorial Board

4. Guest editing a special issue

For more details, please visit:

http://www.lidsen.com/journals/acr 